\title{
THE BEGINNINGS OF MODERN HIGHER EDUCATION IN ENGLAND
}

\author{
Gabriela MIHĂILĂ-LICĂ \\ “Nicolae Bălcescu" Land Forces Academy, Sibiu, Romania \\ mihailag2001@yahoo.com
}

\begin{abstract}
Realizing that a people can not be entirely conquered unless it is educated to embrace the culture and civilization of the conquerors, the Romans established the first schools in Britain in order to 'romanize the sons of native chieftains' [1]. With the arrival of Christianity, associated with the mission of Augustine in 597 AD, the churches took upon themselves the mission of teaching reading, writing and some religious knowledge, but few men benefited from this. The schools in the cathedrals and monasteries gradually grew to become universities, their main objective being to make students understand and explain the truth of God. "After the year 1000, cathedral schools replaced monasteries as cultural centres, and new forms of learning emerged. The cathedral schools were in turn supplanted by the universities, which promoted a "Catholic" learning that was inspired, oddly enough, by the transmission of the work of Aristotle through Arab scholars." [2]. The paper analyses in broad lines the lengthy and burdensome process the English universities went through until the beginning of the $20^{\text {th }}$ century in order to reach the performance of forming people capable not only of doing research and of disseminating knowledge, but also of contributing to the development of the country.
\end{abstract}

\section{Keywords: modern, higher education, England, universities}

\section{Introduction}

The United Kingdom prides itself with some of the most successful and most famous universities in the world. The universities of Oxford and Cambridge are considered to be the oldest in England, the former having its origins in the twelfth century and the latter in the thirteenth century.

These two universities became more visible in the $13^{\text {th }}$ century when they were viewed as "centres of professional training, preparing men for careers as teachers, preachers, lawyers, officials and administrators. They were not concerned with the pursuit of knowledge for its own sake or with research. Such things were intellectual luxuries which society in general and students individually could not afford" [3].

\section{Medieval Education in England}

Since according to the doctrine of the medieval church, the truth did not have to be discovered through research and experiments as it was already written in the Bible and in the works of Aristotle, Plato or other renowned ancient philosophers and scientists, the clergy made it their mission to learn, to interpret and explain the truth for the rest of the people. "The seven liberal arts, dating from the fifth century, formed the basis of the universities' teaching. The trivium of grammar, logic and rhetoric led to the degree of bachelor; the quadrivium of arithmetic, music, geometry and astronomy led to the degree of master" [4]. The teaching was carried out by masters who had themselves undertaken the course and who had received the approval of or were 'licensed' by the other colleagues.

Owing to the fact that scholars benefited from various privileges, in 1231 Henry III ordered that all the students at Oxford and Cambridge "were to have their names entered on the roll (matricula) of a licensed 
master or regent" [5]. Historians mention ceremonies when students wore special gowns and caps for the celebration of graduation, a tradition that has survived with slight changes to this day.

The history of higher education in England is marked, until the Victorian era, by frequent conflicts between the students and the populace of the towns in the vicinity of the two universities and, it is interesting to observe that, when involved, the monarchs usually sided with the scholars.

The novelty brought by the $14^{\text {th }}$ century in the domain of higher education is the important role the universities play in national life. Even if the "Church regulated and defined an individual's life, literally, from birth to death and was thought to continue its hold over the person's soul in the afterlife" [6], the universities succeeded in gaining independence from its control. The graduates of these institutions managed to obtain high positions in politics, in the management of the state and of the church [7].

A century later, specialists noticed an increasing interest in education and higher literacy levels; one factor that contributed in a decisive manner to the advancement of education, especially of the lay one, was the replacement of French by English and the printing press brought to England in 1476 by William Caxton.

Education was achieved not only with the help of schools and universities, but also through apprenticeship and later through employment. The church adjusted its objectives as it tried to counteract the escalating heresy more strongly, to increase the number of clergy depleted by the wars and epidemics and to help those who wanted "to qualify in canon and civil law" [8].

Joan Simon is of the opinion that the developments of the English education in fifteenth-century were still far behind those in the Italian states, "but there was a slow maturing of change in institutions and attitudes which laid the foundation for a durable advance in the next century" [9].

\section{Education during the Renaissance}

Throughout the Renaissance, a cultural and artistic movement that appeared in Italy in the $14^{\text {th }}$ century, but that arrived in England only during the Elizabethan age, in the $16^{\text {th }}$ century, the education focused more on secular subjects. The Tudor monarchs, they themselves very learned persons, invested money (Henry VIII helped both universities with royal foundations) and effort to make education available to as many people as possible. Leach estimates that at the start of Henry's reign "England had about 400 schools for a population of 2.25 million, or one school for every 5,625 people [10].

Lawson, J. and Silver point out that it is during this period that humanism "changed medieval attitudes to women, or at least to women of the upper class" [11] Tudor noble women who could speak several languages, played musical instruments, did needlework and managed homes.

\section{Education during the $17^{\text {th }}$ and $18^{\text {th }}$ centuries}

The following century is marked by the passing of the Act of Uniformity in 1662, which gave permission to the religious dissenters to establish academies, an example of these being the Bristol Baptist College, where those who did not wish to accept the Thirty Nine Articles of the Church of England could pursue their higher studies. The number of dissenting universities multiplied in the eighteenth century and so did that of the medical schools.

\section{Education during the $19^{\text {th }}$ century}

The $19^{\text {th }}$ century is characterized by important events (the abolition of slavery, the Industrial Revolutions, the expansion of the colonial British Empire) that changed not only the way people lived, but also their beliefs and the way they viewed their education and that of their children. During this time, people, more than during the previous periods, began to consider education as one the most important ingredients that ensured the success of a person and it was also a modality of building morality and of shaping an individual's 
character. Laws were passed with the intention of making schooling compulsory for a great percentage of the population, even though there still remained great disparities between the educational levels of the social classes as well as between those of the men and women. The politicians understood that by education and by spreading literacy levels, they would reduce poverty and crime. Thus, in 1807, "Samuel Whitbread proposed to deal with the whole of the Poor Law with the introduction of a Bill in the House of Commons" [12]. According to this bill, all children were required to have two years of education. Unfortunately, the idea of generalized education did not materialize then but much later and 1870, the year when the Education Act was passed, is considered by specialists "the birth of the modern system of education in England" [13]. Just like during the previous centuries, education started at home. It was done by the parents, the authoritarian parenting style being the norm, by the church, by the community and later it was supplemented and continued by schools and universities. There appeared all over Britain a variety of schools meant to cater for the learning needs of children and of young people of various financial means and even for those without any means at all.

The universities of Oxford and Cambridge did not seem to enjoy too much popularity mainly due to the fact that the range of careers that graduates could embrace was very limited. Another reason for this dwindling popularity is the obligation of the students to subscribe to the Thirty-Nine Articles, the doctrinary declaration of the Church of England. Moreover, all those who wanted to teach had to be ordained first as Anglican priests. The courses were very expensive and few people, usually members of the higher social classes, could afford them. The high costs led to a greater need for scholarships, (the bulk being in classics and mathematics) and this influenced the curriculum. "The provision of fellowships had a similar effect. Most fellowships were tied to classics at Oxford and mathematics at Cambridge" [14]. The power struggle "within the institutions between the university and the colleges" intensified [15]. In the case of the institutions mentioned above, the colleges, which were managed in the manner of private companies, had more power and finances than the universities. The classics and mathematics were cheap to teach and no expensive equipment or libraries were needed. Furthermore, these subjects also helped colleges to have more autonomy.

Mark Pattison and Henry Halford Vaughan believed that one of the main objectives of a university was to do research, to find new knowledge, but their opinion was not shared by all the scholars at that time. "The financial provision of scholarships and fellowships outside the classics and mathematics brought conflict with the curricular conservatism in college-based anti-research teaching" [16]. The study of the classics was intended to develop the intellectual, the moral and social qualities of the students, preparing them for civil service, but not for any job in particular. It was only after the reform started in the second half of the $19^{\text {th }}$ century that Nonconformists were allowed to enlist, to graduate and even to become fellows without being ordained. A number of non-sectarian colleges were open "in London from 1828 onwards, grouped into London University in 1836. Durham University was founded in 1832, Owens College in Manchester in 1851, and Birmingham University in 1900. Furthermore, historians noted a diversification of the curricula and a greater prominence of research.

New medical schools were founded in Manchester (1825), Sheffield (1827), Birmingham (1828), Bristol (1828), Leeds (1830), Liverpool (1834) and Newcastle (1834). These schools and the University of London represented an opposition to the old universities of Oxford and Cambridge in the sense that they tried to prepare students for professions needed in the industry and in the business world, the emphasis being laid on practical subjects [17].

The University of London, founded in 1828, "differed from existing institutions in three respects: first, it was free of religious tests and open to nonconformists and unbelievers; secondly, it was to be cheaper than the 
ancient universities to cater for 'middling rich people'; and finally, there was a strong emphasis on professional training in the medical, legal, engineering and economic studies neglected at Oxford and Cambridge. It was to be useful and vocational. The Church of England (...) established their own rival King's College in 1828 as an exclusively Anglican institution but also with a focus on vocational training." Nevertheless, the expectations of the larger part of the English society of the time were not met by Cambridge and Oxford as they did not manage and did not even try to prepare students to deal with the challenges of the epoch, especially with industrialization; they continued to produce "clergy, gentlemen and, after 1850, civil servants" [18].

\section{The education of women}

Until the $20^{\text {th }}$ century, the ideal "career" a woman had been expected to follow was that of wife and mother. Even though one can see that women are given the opportunity to access higher levels of education, for the great majority of them, formal schooling ended around the age of eleven. "Most girls particularly those from working class backgrounds - finished formal schooling at 11. While there were evening schools for the ambitious working class, particularly in metropolitan areas such as London, 85 per cent of their intake was male. All of which left young women with few opportunities outside of factory labour, domestic service or marriage. Even at the top end of the socioeconomic spectrum, the formal education of women was not considered a priority compared to the ambition of marrying favourably" [19]. In the case of the women from the upper classes one can speak of a slightly higher amount of education. Those who could afford it hired governesses to teach their daughters and nieces to entertain guests, to play the piano, to paint, to arrange flowers. The women who did not marry did not have too many choices of earning a living. They could become governesses or spinster daughters and aunts whose help was needed to care for the children and the elderly. The establishment of the Queen's College, London in 1848 and that of Cheltenham Ladies' College, for governesses, shows an increase in female education, increase that encouraged the women to intensify their struggle for the right to vote.

The universities of Oxford and Cambridge continued to preserve the three centennial conditions for admission 1: being male; 2 : being unmarried; and 3: being a member of the Church of England. It is only in the $20^{\text {th }}$ century that the first women were admitted here. In 1878 London University admitted women to two colleges, Bedford College, and the Royal Holloway College (...)" [20]. It is during this period that women begin to graduate from university and pursue careers in fields like medicine that until that time had been the exclusive prerogative of men. Nonetheless, the English higher education for women still lagged behind in comparison to other countries. In the USA they started gaining degrees since 1841, while "in Britain women were first awarded degrees in 1880" [21].

\section{Conclusion}

After having analyzed the major changes that occurred throughout the history of the English higher education until the beginning of the $20^{\text {th }}$ century, we can obtain a clearer picture of the major role played by the various measures undertaken throughout the centuries, especially during the Victorian era, for the modernization of the education in England. It was an age when more people than ever before had access to education, even if there were still very few those who were fortunate enough to manage to enlist and to graduate from universities. "During the decade between 1855 and 1865 only one in 77,000 went to university. Higher education was still accessible to only a small minority" [22]. In this time of many "firsts" in the history of English education (compulsory and free primary education, the graduation of women from university in domains that had usually been the prerogatives of men, the diversification of the curriculum in order to prepare students for careers in industry and the business 
environment), one can see that the bases are

university - society.

laid for a mutual beneficial partnership

\section{References List}

[1] Lawson, J, Silver, H, A Social History of Education in England, London: Methuen \& Co Ltd, 1973, p. 7

[2] https://www.britannica.com/topic/Roman-Catholicism/The-church-of-the-early-MiddleAges, 05.02.2021

[3] Lawson, J. and Silver, H., A Social History of Education in England, London: Methuen \& Co Ltd, 1973, p. 31

[4] Gillard, Derek, Education in England: a History, http://www.educationengland.org.uk/history/chapter01.html, 12.02.2021

[5] Lawson, J. and Silver, H., A Social History of Education in England, London: Methuen \& Co Ltd, 1973, p. 52

[6] Mark, Joshua J., The Medieval Church, https://www.ancient.eu/Medieval_Church/ 05.02.2021

[7] Lawson, J. and Silver, H., A Social History of Education in England, London: Methuen \& Co Ltd, 1973, p. 54

[8] Simon, J, Education and Society in Tudor England Cambridge: Cambridge University Press, 1966, p. 40.

[9] Ibidem, p. 56.

[10] Leach, AF, The Schools of Medieval England London: Methuen \& Co. Ltd, 1915, p. 331

[11] Lawson, J. and Silver, H., A Social History of Education in England, London: Methuen \& Co Ltd, 1973, p. 121

[12] [12] Walsh, Robert, Education in Britain, http://www.knowbritain.com/general/education_in_england_2.html, 09.02.2021

[13] Ibidem

[14] University education 1800-1870, https://richardjohnbr.blogspot.com/2011/02/universityeducation-1800-1870.html, 09.02.2021

[15] Ibidem

[16] See, Pattison, Mark, Suggestions on academical organisation with especial reference to Oxford, (Edmonston and Douglas), 1868, Sparrow, John, Mark Pattison and the Idea of a University, (Cambridge University Press), 1967, 2008, Jones, H. Stuart, Bill, Intellect and character in Victorian England: Mark Pattison and the invention of the don, (Cambridge University Press), 2007, E.G.W., University reform in nineteenth-century Oxford: a study of Henry Halford Vaughan, 1811-1885, (Oxford University Press), 1973 retrieved from University education 1800-1870, https://richardjohnbr.blogspot.com/2011/02/universityeducation-1800-1870.html , 11.02.2021

[17] https://richardjohnbr.blogspot.com/2011/02/university-education-1800-1870.html, 09.02.2021

[18] https://richardjohnbr.blogspot.com/2011/02/university-education-1800-1870.html, 09.02.2021

[19] https://www.bl.uk/collection-items/picture-of-a-female-graduate-of-london-universityfrom-the-graphic, 09.02.2021

[20] Picard, Liza, Education in Victorian Britain, https://www.bl.uk/victorianbritain/articles/education-in-victorian-britain , 09.02.2021

[21] Lambert, Tim, A Brief History of Education, http://www.localhistories.org/education.html, 09.02.2021

[22] https://richardjohnbr.blogspot.com/2011/02/university-education-1800-1870.html, 11.02.2021 